\title{
Perkembangan Destinasi Pariwisata dan Kualitas Hidup Masyarakat Lokal
}

\author{
1) FITRI ABDILLAH, ${ }^{2)}$ JANIANTON DAMANIK, 3) CHAFID FANDELI, 4) SUDARMADJI
}

\author{
1,2,3,4) Sekolah Pasca Sarjana Universitas Gadjahmada Yogyakarta, Indonesia \\ email: fitri_adie@yahoo.com
}

\begin{abstract}
This article investigated how does local community respon destination development through perceptions of their quality of life. It conducted by survey method in two tourism destinations, Pananjung, Pangandaran and Citepus, Palabuhanratu, West Java. Primary data was taken as many as 279 samples are local communities by purposive sampling. All of data analized by descriptive statistics, tabulation and perception index number. The result shows that Pangandaran has better performance of destination attribute and better index of quality of life than Palabuhanratu. Pangandaran is in the phase of development, while Palabuhanratu is in consolidation phase. It means consolidation phase is lower condition than development. Among four aspects of quality of life, the material aspect is at the highest position, followed by the spiritual, the social and personal aspect. There are positive correlation between destination development and quality of life level of local community. It means tourism destination development must be understood as the increasing number of tourist which contribute to performance of destination and level of local quality of life.
\end{abstract}

Keywords: destination development, quality of life, local people

\begin{abstract}
Abstrak. Tulisan ini mendalami perkembangan destinasi pariwisata dan persepsi masyarakat lokal terhadap kualitas hidupnya. Penelitian dilakukan dengan metode survey di dua destinasi pariwisata, Desa Pananjung, Pangandaran dan Desa Citepus, Palabuhanratu. Sebanyak 279 sampel penelitian diambil dari masyarakat lokal di kedua desa secara purposif. Data primer dan data sekunder diolah dan dianalisis dengan metode deskriptif dengan tabulasi dan angka indeks persepsi. Hasil penelitian menunjukkan bahwa Pangandaran memiliki kinerja yang lebih baik dibandingkan dengan Palabuhanratu. Pangandaran berada pada fase pertumbuhan dan Palabuhanratu berada pada fase konsolidasi pada siklus hidup destinasi pariwisata. Diantara keempat aspek kualitas hidup, aspek material berada pada posisi tertinggi disusul oleh aspek spiritual, aspek sosial dan aspek pribadi. Terdapat hubungan positif antara perkembangan destinasi pariwisata dengan kualitas kehidupan masyarakat secara keseluruhan. Dengan demikian, perkembangan destinasi pariwisata adalah pertumbuhan jumlah wisatawan yang meningkatkan atribut destinasi serta kualitas hidup masyarakat secara keseluruhan.
\end{abstract}

Kata kunci: destinasi pariwisata, kualitas hidup, masyarakat lokal

\section{Pendahuluan}

Dalam khazanah perkembangan destinasi pariwisata, hal menarik yang selalu menjadi tantangan adalah terciptanya pola pembangunan yang tidak hanya mengedepankan pembangunan fisik semata akan tetapi juga mengakomodasi kepentingan masyarakat untuk lebih sejahtera. Dalam UU
No 10 Tahun 2009 tentang Kepariwisataan disebutkan bahwa pariwisata diselenggarakan untuk meningkatkan kinerja ekonomi, meningkatkan kesejahteraan, pelestarian alam dan memperkokoh jatidiri bangsa Indonesia. Pembangunan pariwisata diselenggarakan dengan prinsip menjunjung tinggi hak asasi manusia, keragaman budaya, dan kearifan lokal, dan memberi manfaat untuk

Received: 12 Juni 2015, Revision: 24 September 2015, Accepted: 27Desember 2015

Print ISSN: 0215-8175; Online ISSN: 2303-2499. Copyright@2015. Published by Pusat Penerbitan Universitas (P2U) LPPM Unisba Terakreditasi SK Kemendikbud, No.040/P/2014, berlaku 18-02-2014 s.d 18-02-2019 
kesejahteraan rakyat. Dengan kata lain, pariwisata dikembangkan dalam rangka untuk meningkatkan kualitas hidup masyarakat lokal.

Atas dasar prinsip tersebut maka pengembangan destinasi pariwisata sesungguhnya merupakan implementasi layanan kepada wisatawan dengan tidak mengabaikan kepentingan masyarakat lokal. Dengan demikian prinsip keberlanjutan diacu sebagai dasar pembangunan destinasi pariwisata, meliputi tiga dimensi yaitu lingkungan, sosial, dan ekonomi (Fauzi dan Oktavianus, 2014). Interaksi masyarakat dengan wisatawan menciptakan keseimbangan ekonomi, lingkungan dan sosial yang lebih baik.

Benckendorff et al, (2009) menyatakan bahwa meskipun pariwisata diakui memiliki hubungan positif dengan kualitas hidup akan tetapi topik ini masih menjadi perdebatan dalam berbagai bidang keilmuan. Studi tentang dampak menjelaskan persetujuan masyarakat tentang dampak pembangunan, sedangkan studi tentang kualitas hidup lebih menekankan pada tingkat kepuasan mereka terhadap kehidupannya. Hal tersebut dapat diartikan bahwa belum tentu persetujuan masyarakat tentang dampak mengindikasikan tingkat kepuasan hidup masyarakat terhadap lingkungannya.

Tingkat kualitas hidup masyarakat sangat penting untuk menjaga kesinambungan destinasi itu sendiri. Faktor keamanan misalnya, jika wisatawan dapat menikmati kenyamanan seperti yang diharapkan, maka pada waktu yang akan datang wisatawan akan berkunjung kembali. Faktor keamanan sangat berhubungan dengan tingkat kualitas hidup masyarakat setempat. Masyarakat yang memiliki kualitas hidup baik akan memiliki tingkat kesejahteraan lebih baik, tingkat pendidikan yang lebih baik serta kesehatan lebih baik dibandingkan masyarakat yang kualitas hidupnya lebih rendah. Dengan kualitas tersebut maka dapat diharapkan masyarakat menjadi lebih kreatif untuk menciptakan peluang-peluang usaha yang bermuara pada rendahnya tingkat pengangguran.

Sebagai salah satu destinasi pariwisata di Indonesia, Provinsi Jawa Barat menempati posisi strategis, sebab kedekatan geografisnya dengan DKI Jakarta. Kedekatan ini menyebabkan melimpahnya kunjungan wisatawan dari DKI Jakarta ke Jawa Barat. Meskipun demikian, Jawa Barat baru berkontribusi lebih kurang sepuluh persen dari kinerja pariwisata nasional. Demikian halnya dengan kondisi kualitas hidup masyarakatnya. Secara objektif ratarata tingkat kualitas hidup masyarakat lokal Jawa Barat masih lebih rendah dari rata-rata tingkat kualitas hidup Indonesia. Dalam pengembangan destinasi pariwisata, Jawa Barat menetapkan wilayah pembangunan dalam sembilan kawasan wisata unggulan (KWU). Dari sembilan KWU tersebut, terdapat dua yang memiliki keunikan berupa tema pembangunan yang mengandalkan pariwisata pantai sebagai tema yaitu Pangandaran dan Palabuhanratu. Kedua wilayah secara tradisional telah dikenal sebagai destinasi pariwisata dan memiliki kunjungan wisatawan lebih dari lima ratus ribu orang per tahun.

Artikel ini mendalami bagaimana persepsi masyarakat lokal terhadap kualitas hidupnya di Pangandaran dan Palabuhanratu. Tujuan penelitian ini adalah untuk (1) menganalisis tingkat perkembangan destinasi Pangandaran dan Palabuhanratu; (2) menilai persepsi masyarakat tentang tingkat kualitas hidupnya; (3) menganalisis keterkaitan antara perkembangan destinasi pariwisata yang diwakili oleh perkembangan wisatawan dan tingkat kualitas hidup masyarakat lokal.

Bahasan ini menarik oleh sebab apakah memang terdapat keterkaitan antara perkembangan destinasi pariwisata dan kualitas hidup masyarakat lokal sesuai yang dikemukakan oleh Jurowski dan Brown (2001). Keeratan hubungan membuktikan bahwa pembangunan destinasi pariwisata memang berkembang secara seimbang antara kepentingan wisatawan dan masyarakat lokal.

\section{Perkembangan Destinasi Pariwisata}

Konsep destinasi pariwisata merupakan salah satu yang paling penting dan kompleks dalam pembahasan pariwisata. Gunn dan Var (1994) melihat destinasi pariwisata sebagai area pasar perjalanan wisata dan merujuk pada zona tujuan perjalanan yaitu area geografis yang meliputi pembangunan wilayah dan masyarakat dalam rangka memuaskan tujuan perjalanan wisatawan. Oleh sebab itu destinasi pariwisata dapat dijelaskan pada skala yang berbeda mulai dari level desa sampai dengan wilayah, kota atau resort, situs khusus dan bahkan hanya berujud atraksi khusus yang dikunjungi wisatawan.

Sebagai sebuah sistem dinamis, pariwisata merupakan interaksi berbagai komponen tempat masyarakat lokal termasuk 
di dalamnya. Interaksi ini memiliki konsekuensi positif dan negatif yang harus dimonitor agar destinasi pariwisata dapat selalu berkembang (Sheldon dan Abenoja, 2001). Hubungan antara tingkat perkembangan destinasi pariwisata dengan dampak pengembangannya telah dikaji oleh banyak peneliti, seperti siklus hidup area wisatawan (Butler R., 1980, Butler, 2011), perubahan sosial (Liu dan Var, 1986; Dietrich dan García, 2008), dan kualitas hidup (Jurowski dan Brown, 2001; Kim, 2002). Dari berbagai teori tersebut tampaknya teori tentang siklus hidup destinasi pariwisata memperoleh perhatian luas dengan seringnya model ini digunakan sebagai alat untuk membantu memetakan dampak perkembangan destinasi pariwisata.

Dietrich dan García (2008) menyatakan bahwa terdapat hubungan kuat antara persepsi masyarakat terhadap dampak perkembangan pariwisata dengan tahap perkembangan destinasi itu sendiri. Pada tahap awal perkembangan menunjukkan bahwa masyarakat lokal cenderung memiliki sikap positif, namun setelah pembangunan menjadi massif dan tidak teratur maka persepsinya menjadi berubah. Penelitian Dyer, et al., (2006), menyatakan bahwa pada destinasi yang maju masyarakat mengabaikan sikap positif terhadap budaya meskipun mereka tetap mendukung perkembangan destinasi pariwisata. Persepsi ini terbentuk oleh perilaku masyarakat yang terlibat, baik secara langsung maupun tidak langsung dalam perkembangan pariwisata.

Butler (1980) menyusun konsep tentang perkembangan destinasi pariwisata. Destinasi akan berkembang menurut model siklis dimulai dari tidak adanya aktivitas wisata (nil tourism) sampai dengan pembangunan masif dalam bentuk eksploitasi massal (massive development) dan selanjutnya terjadi kejenuhan dan penurunan. Konsep ini digunakan sebagai basis analisis dengan melihat karakteristik perkembangan menggunakan lima atribut destinasi pariwisata

\section{Kualitas Hidup Masyarakat Lokal}

Susniene \& Jurkauskas (2009) menyatakan bahwa sampai saat ini tidak ada konsep kualitas hidup tunggal yang dinyatakan dan diterima secara universal, oleh sebab konsep kualitas hidup didiskusikan pada berbagai ranah keilmuan. Pada bidang sosiologi kualitas hidup diartikan sebagai pemahaman subjektif dari kepemilikan (well-being). Pada bidang ekonomi, kualitas hidup diartikan sebagai standar kehidupan (standard of living), sedangkan pada bidang farmasi dan kedokteran, kualitas hidup adalah rasio antara waktu sehat dan sakit dengan berbagai faktor yang mempengaruhi gaya hidup sehat.

Kualitas hidup dapat dipandang dalam konteks objektif atau subjektif. Kualitas hidup dalam konteks objektif seringkali dipandang secara makro dengan menggunakan alat ukur umum dan merupakan konsensus yang disepakati oleh banyak negara di dunia. Morris dan Alpin (1982) misalnya mengemukakan konsep Physical Quality of Life Index (PQLI) atau Indeks Kualitas Hidup Fisik. Ukuran ini memberi gambaran sesuatu yang sudah dicapai dalam pembangunan dan pemerataan pembangunan. Ada tiga unsur yang tercakup dalam indeks tersebut yakni: angka kematian bayi, angka harapan hidup dan angka melek huruf.

Dalam konteks subjektif, Kim (2002) menjelaskan bahwa kualitas hidup merupakan aspek subjektif yang ditentukan oleh empat aspek yaitu material, komunitas, emosional, serta kesehatan dan keamanan. Mengacu pada wacana penelitian tersebut, konsep ideal terhadap kualitas hidup ditentukan oleh pendekatan objektif yang didukung oleh pendekatan subjektif. Namun demikian meskipun penilaian objektif lebih mudah dilakukan, penilaian subjektif lebih mendominasi pembahasan, mengingat ukurannya merupakan ukuran mikro pada suatu wilayah tertentu. Pendekatan konsep Kim (2002) tentang empat domain kualitas kehidupan, digunakan sebagai acuan menentukan tingkat kualitas hidup masyarakat lokal. Untuk itu maka kualitas hidup masyarakat lokal didefinisikan sebagai tingkat kepuasan terhadap aspek material, aspek sosial, aspek pribadi, dan aspek spiritual.

Jurowski (1994) menyatakan bahwa kualitas hidup masyarakat lokal akan terpengaruh sebagai konsekuensi dari pembangunan destinasi pariwisata. Studistudi tentang hubungan antara pembangunan destinasi pariwisata dengan kualitas hidup masyarakat menunjukkan ada hubungan positif (Kim, 2002; E, Eraqi, 2007; Aref, 2011).

Pada studi yang lain Liu dan Var (1986) menyatakan bahwa masyarakat menyadari bahwa pariwisata dapat memberikan dampak ekonomi secara signifikan tetapi mereka enggan untuk menerima perubahan 
lingkungan dan sosial akibat pariwisata. Oleh sebab itu keuntungan ekonomi yang secara tradisional diasosiasikan dengan pembangunan pariwisata harus diperbandingkan dengan efek sosial yang harus ditanggung akibat pembangunan pariwisata tersebut.

Kualitas hidup dalam tulisan ini diartikan sebagai kepuasan individu terhadap seluruh dimensi kehidupannya (Susniene and Jurkauskas, 2009). Kualitas hidup masyarakat lokal diukur secara subjektif dan dikelompokkan dalam empat aspek yang meliputi aspek kehidupan material, aspek kehidupan sosial, aspek kehidupan pribadi, dan aspek kehidupan spiritual . Konsepkonsep tersebut digunakan sebagai basis analisis untuk memunculkan parameterparameter aspek-aspek kualitas hidup.

Artikel ini merupakan penelitian survei dilakukan dengan menggabungkan pendekatan kuantitatif dan kualitatif. Lokasi penelitian adalah Pangandaran yang diwakili oleh Desa Pananjung, Kecamatan Pangandaran, Kabupaten Ciamis, dan Palabuhanratu, yang diwakili oleh Desa Citepus, Kecamatan Palabuhanratu, Jawa Barat.

Data sekunder lebih banyak digunakan dengan menelusuri perkembangan Pangandaran dan Palabuhanratu sebagai destinasi pariwisata. Kualitas hidup masyarakat ditentukan dengan nilai persepsi terhadap empat aspek kualitas hidup yaitu aspek material, aspek sosial, aspek pribadi, dan aspek spiritual. Penggunaan data sekunder ini kemudian dipadukan dengan data primer berupa indepth interview dan observasi lapangan. Sampel diambil secara purposif di kedua wilayah dengan total sampel maksimal 300 sampel.

\section{Perkembangan "destinasi" pariwisata dan tingkat kualitas hidup masyarakat lokal}

Terdapat dua variabel utama penelitian yaitu perkembangan destinasi pariwisata dan tingkat kualitas hidup masyarakat lokal. Secara umum, perkembangan destinasi pariwisata mengikuti pola yang dikenal dengan siklus hidup destinasi pariwisata. Perkembangan destinasi pariwisat diukur dengan menghitung nilai indeks berdasar pembobotan terhadap masing-masing unsur destinasi pariwisata. Pembobotan dilakukan dengan expert judgement dengan nilai maksimal 1 . Nilai indeks selanjutnya digunakan untuk memplot tingkat perkembangan destinasi pariwisata dalam Kurva Butler (1980). Penentuan plot mengikuti kriteria sebagai berikut.

Tabel 1

Nilai Interval Konversi Skor ke Interpretasi Perkembangan Destinasi

\begin{tabular}{|r|l|l|}
\hline $\begin{array}{r}\text { Nilai Interval } \\
\text { Skor } \\
\text { Akhir }\end{array}$ & Interpretasi & \multicolumn{1}{|c|}{ Plot } \\
\hline $0,333-0,466$ & Sangat rendah & Stagnasi \\
\hline $0,467-0,600$ & Rendah & Konsolidasi \\
\hline $0,601-0,733$ & Sedang & Konsolidasi \\
\hline $0,734-0,867$ & Tinggi & Pertumbuhan \\
\hline $0,868-1,000$ & Sangat tinggi & Pertumbuhan \\
\hline
\end{tabular}

Kualitas hidup masyarakat ditandai dengan persepsi terhadap aspek material, aspek sosial, aspek pribadi, dan aspek spiritual. Untuk mendeskripsikan variabelvariabel secara mandiri digunakan statistika deskriptif dan angka indeks persepsi. Kriteria nilai indeks persepsi kualitas hidup adalah sebagai berikut.

Tabel 2

Nilai Interval Konversi Skor Persepsi ke Interpretasi Tingkat Kualitas Hidup

\begin{tabular}{|c|c|c|c|}
\hline 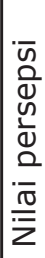 & 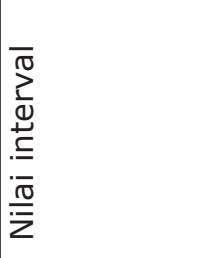 & 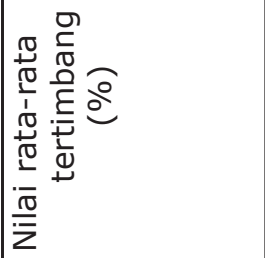 & 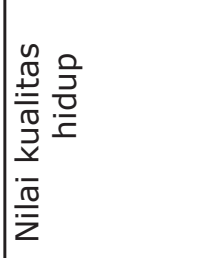 \\
\hline 1 & $1.00-1.79$ & $20.00-35.99$ & Sangat \\
\hline 2 & $1.80-2.59$ & $36.00-51.99$ & Rendah \\
\hline 3 & $2.60-3.39$ & $52.00-67.99$ & Sedang \\
\hline 4 & $3.40-4.19$ & $68.00-83.99$ & Tinggi \\
\hline 5 & $4.20-5.00$ & $84.00-100.00$ & $\begin{array}{c}\text { Sangat } \\
\text { Tinggi }\end{array}$ \\
\hline
\end{tabular}

\section{Perkembangan Destinasi Pariwisata}

Pembahasan tentang perkembangan destinasi pariwisata merupakan pembahasan tentang atribut-atribut destinasi pariwisata. Di antara berbagai peneliti tersebut tampaknya pendekatan Buhalis (2000) dan Inskeep (1991), yang menyatakan bahwa destinasi pariwisata memiliki determinan wisata berupa wisatawan, atraksi wisata, aksesibilitas, amenitas dan akomodasi, lebih mudah untuk diaplikasikan, dibandingkan dengan atribut yang dikemukakan peneliti lain.

Dalam hal jumlah wisatawan, data menunjukkan bahwa Palabuhanratu memiliki jumlah wisatawan yang lebih tinggi dibandingkan dengan Pangandaran. Wisatawan Nusantara (wisnus) yang 
berkunjung ke Palabuhanratu lebih dominan berasal dari Jakarta dan sekitarnya, sedangkan wisnus yang berkunjung ke Pangandaran lebih dominan berasal dari Bandung dan sekitarnya. Kunjungan yang lebih besar disebabkan oleh jumlah penduduk Jakarta dan sekitarnya lebih besar dibandingkan dengan Bandung dan sekitarnya. Disamping itu, jarak tempuh dari Jakarta ke Palabuhanratu lebih dekat dibandingkan dengan jarak tempuh dari Bandung ke Pangandaran. Kunjungan wisatawan ini merupakan implementasi dari pilihan wisatawan menentukan destinasi pariwisata berdasar atributnya (Saraniemi dan Kylänen, 2011). Gambar berikut menunjukkan perkembangan atribut destinasi pariwisata di Pangandaran dan Palabuhanratu.

Hal di atas menyebabkan kunjungan ke Palabuhanratu lebih tinggi dibandingkan dengan ke Pangandaran. Namun demikian, jarak yang lebih dekat memunculkan karakter lokal wisatawan yang lebih tinggi di Palabuhanratu. Karakter lokal dicirikan oleh waktu kunjungan yang pendek; berkelompok dengan menggunakan moda transportasi pribadi baik mobil, motor, maupun mobil barang; serta membawa bekal untuk berrekreasi di pantai. Dengan karakter lokal yang lebih tinggi tersebut maka hanya sebagian kecil wisatawan tersebut menginap pada akomodasi yang tersedia. Sampah yang ditinggalkan seringkali menyebabkan kekumuhan.

Pada kedua wilayah, diperoleh kesan yang sama tentang musim kunjungan wisatawan yang memanfaatkan hari libur nasional dan akhir pekan untuk berkunjung. Karena waktu liburan yang terbatas, pada hari-hari libur nasional pada kedua wilayah terjadi lonjakan jumlah wisatawan yang melebihi kapasitas lokasi, sehingga kemacetan lalulintas tidak dapat dihindari. Hal ini

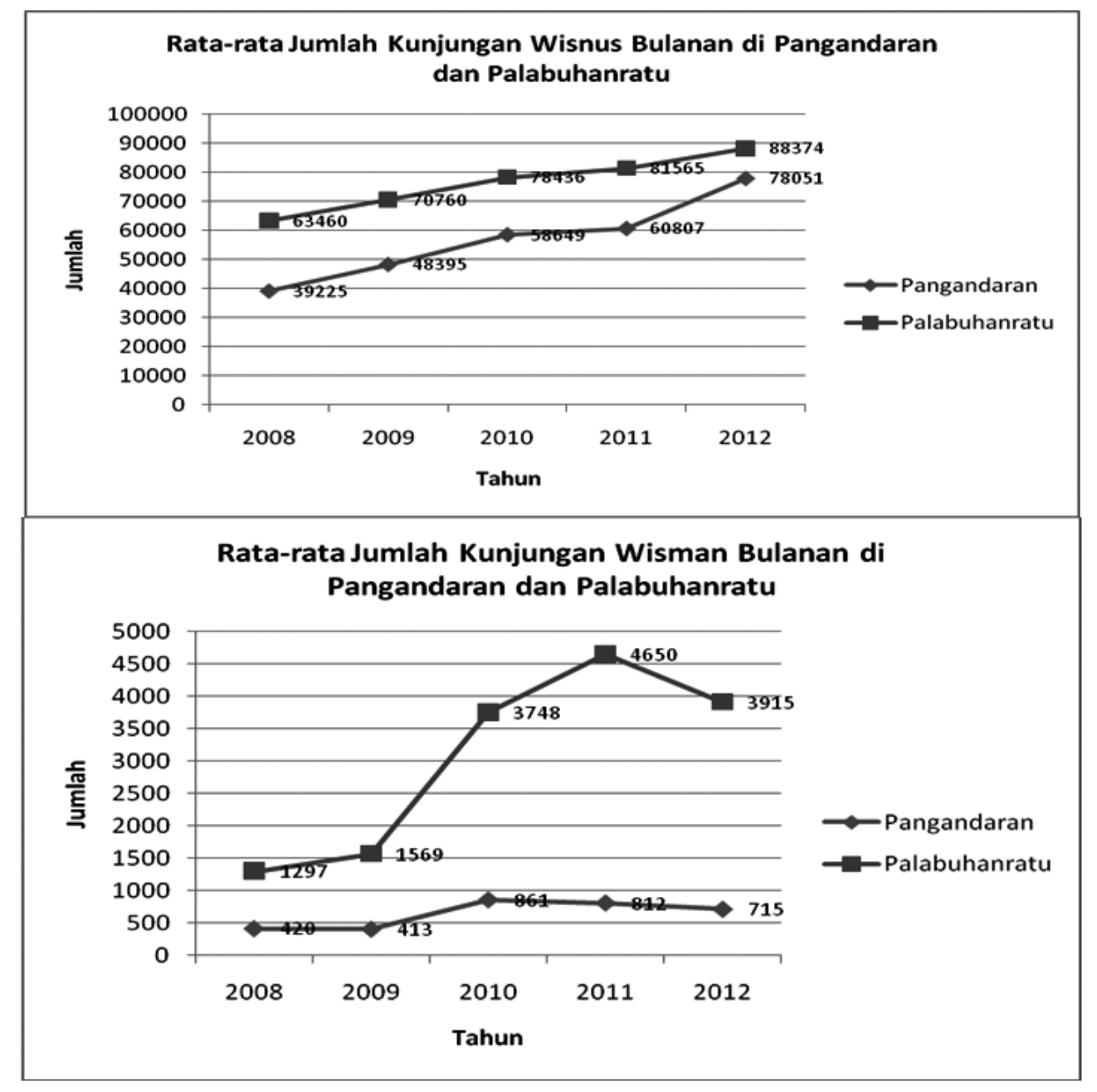

Gambar 1

Rata-rata Perkembangan Wisatawan Bulanan per Tahun di Pangandaran dan Palabuhan Ratu Tahun 2008 s.d. 2012 (sumber: data primer, 2014) 
kemudian disikapi oleh masyarakat dengan menyambut kunjungan tersebut dengan berbagai aktivitas pelayanan sederhana berupa warung dan tempat istirahat yang dapat mereka lakukan. Pada saat musim liburan telah selesai berbagai dampak berupa sampah dan bangunan kayu menimbulkan kekumuhan yang menyebabkan kualitas destinasi menurun.

Perkembangan akomodasi pada kedua wilayah menunjukkan pola perkembangan yang berbeda. Meskipun data jumlah wisatawan ke Pangandaran lebih kecil dibandingkan ke Palabuhanratu, investasi untuk pembangunan akomodasi lebih nyata terjadi di Pangandaran. Hal ini tercermin dari bertambahnya jumlah hotel-hotel nonbintang dan homestay. Perkembangan ini juga diduga berkaitan dengan jarak yang lebih jauh serta jumlah objek wisata yang harus dikunjungi menyebabkan wisatawan harus menginap di Pangandaran. Wisatawan lebih memilih menginap di hotel nonbintang dan homestay yang ada. Oleh sebab itu, bisnis hotel nonbintang dan homestay lebih diminati di Pangandaran.

Dalam hal atraksi wisata, Pangandaran memiliki pilihan objek dan atraksi wisata yang lebih beragam. Terdapat perbedaan pola sebaran objek antara Pangandaran dan Palabuhanratu dikaitkan dengan wisatawan. Pangandaran memiliki karakter wisatawan yang terpusat di ibukota kecamatan. Objek wisata dikunjungi dan mereka kembali lagi ke kota. Hal ini terjadi karena akses menuju lokasi-lokasi objek tersebut harus kembali melewati Pangandaran. Tidak demikian halnya dengan Palabuhanratu. Meskipun Palabuhanratu merupakan pusat aktivitas pariwisata namun pada sepanjang pantai Palabuhanratu berkembang hotel atau penginapan. Karakter inilah yang menyebabkan wisatawan memiliki berbagai pilihan akomodasi yang tersebar di sepanjang pantai, tanpa harus kembali ke Palabuhanratu.

Pada kedua wilayah ditemukan kenyataan bahwa pertambahan jumlah wisatawan yang tinggi tidak menyebabkan perbaikan infrastruktur. Hal ini tampaknya berkaitan dengan visi pemerintah daerah yang belum berpihak pada pariwisata meskipun diakui pariwisata berperan penting dalam pembangunan daerah. Dengan berbagai potensi geologis yang ada di sekitar Pangandaran dan Palabuhanratu, kepentingan pariwisata dapat diabaikan oleh kepentingan lainnya, terutama oleh kepentingan pertambangan. Kontribusi PAD dari sektor pariwisata tidak sepenuhnya dikembalikan untuk mendukung perkembangan pariwisata.

Seethanah etal. (2011) menggarisbawahi kenyataan bahwa,

Infrastruktur pariwisata merupakan faktor penting untuk menciptakan kebanggaan terhadap destinasi bagi masyarakat setempat di samping harga, jarak, dan pendapatan wisatawan di negara asal. Kebanggaan inilah yang kemudian memberikan dampak pada pelayanan yang lebih baik kepada wisatawan yang berasal dari berbagai negara.

Temuan lanjutan dari perkembangan infrastruktur yang baik adalah dukungan pada kebijakan pemerintah untuk meningkatkan peringkat daya saing internasional dari destinasi tersebut. Peningkatan ini terjadi baisanya didahului oleh peningkatan kualitas produk pariwisata terutama dalam hal layanan kepada wisatawan.

Produk pariwisata adalah yaitu suatu susunan produk yang terdiri dari objek dan daya tarik wisata, transportasi, akomodasi, fasilitas, dan hiburan, dimana tiap unsur tersebut ditawarkan secara terpisah kepada wisatawan namun saling mendukung dalam meningkatkan citra destinasi pariwisata.

Terdapat fenomena menarik dalam hal jumlah amenitas yang ada. Perkembangan destinasi Palabuhanratu nampaknya lebih merangsang perkembangan amenitas dibandingkan dengan Pangandaran. Hal ini terjadi disebabkan oleh peran Palabuhanratu sebagai ibukota kabupaten dan pusat kegiatan bisnis di Sukabumi bagian selatan terutama perikanan dan pariwisata. Meskipun amenitas diperuntukkan untuk menunjang aktivitas wisata namun fakta menunjukkan bahwa amenitas juga dapat digunakan untuk melayani kebutuhan masyarakat. Klinik dan mini market misalnya, masyarakat lokal dapat memanfaatkan untuk aktivitas sehari-hari. Sebagai pusat bisnis, permintaan terhadap layanan dan barang-barang lebih tinggi sehingga jumlah amenitas lebih berkembang di Palabuhanratu.

Amenitas dijelaskan dalam PP no. 50 tahun 2011 tentang Rencana Induk Pengembangan Pariwisata Nasional sebagai fasilitas pariwisata, yaitu semua jenis sarana yang secara khusus ditujukan untuk mendukung penciptaan kemudahan, kenyamanan, keselamatan wisatawan dalam melakukan kunjungan ke destinasi pariwisata

Dapat dilihat bahwa secara umum, nilai rata-rata perkembangan Pangandaran lebih tinggi dibandingkan rata-rata perkembangan Palabuhanratu. Ilustrasi posisi destinasi 
pariwisata pada kurva Butler (1980) disajikan sebagai berikut.

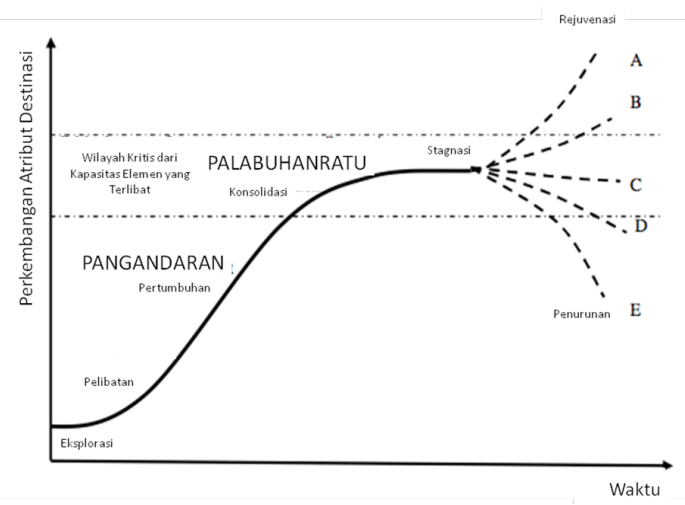

Gambar 2

Pemetaan Ilustratif Destinasi Pangandaran dan

Palabuhanratu dalam Kurva Butler (1980)

Grafik diatas menjelaskan bahwa Butler (1980) menggambarkan perkembangan destinasi pariwisata melalui proses perkembangan yang dimulai dari fase eksplorasi, pelibatan, pertumbuhan, konsolidasi, stagnasi dan penurunan. Masing-masing fase tersebut dicirikan oleh perkembangan beberapa atribut destinasi yaitu wisatawan, akomodasi, objek dan atraksi wisata, aksesibilitas, dan amenitas pariwisata. Hasil perhitungan data menunjukkan bahwa skor indeks yang Pangandaran berada pada skor 0,845 dan Palabuhanratu berada pada skor 0,709. Berdasarkan kategorisasi internval nilai yang ada, angka tersebut mengindikasikan bahwa Pangandaran berada pada fase pertumbuhan dan Palabuhanratu berada pada fase konsolidasi jika di plot dalam kurva Butler (1980).

Hasil penelitian di atas menegaskan pendapat Johnson, et al., (1994), bahwa sampai sekarang model Butler (1980) masih relevan diterapkan sebagai cara untuk memotret perkembangan destinasi pariwisata tanpa harus merunut data dalam jangka waktu yang lama. Dengan pola cross section tersebut maka kebutuhan praktis untuk mengetahui fase perkembangan destinasi pariwisata menjadi lebih praktis.

Aplikasi model Butler (1980) menunjukkan bahwa artikel ini mendukung model tersebut. Tujuan penerapan model ini adalah untuk menduga posisi perkembangan destinasi pariwisata dengan pijakan baku. $\mathrm{Hal}$ ini tampaknya sesuai dengan pendapat Goncalves dan Aguas (1997) yang menyatakan bahwa untuk kepentingan pengambilan keputusan pembangunan, penerapan model tersebut dapat dilakukan. Dengan pijakan baku ini dapat diambil kesimpulan pada fase tertentu memiliki karakteristik keterlibatan dan kualitas hidup tertentu pula.

Dengan demikian, pada fase pertumbuhan, perkembangan jumlah wisatawan lebih memberikan efek pengganda berupa peningkatan usaha akomodasi, atraksi wisata dan usaha-usaha informal masyarakat, dibandingkan dengan destinasi pariwisata pada fase konsolidasi. Perkembangan wisatawan pada kedua fase tersebut tidak secara signifikan menyebabkan perkembangan infrastruktur dan amenitas wisata.

\section{Kualitas Hidup Masyarakat Lokal}

Secara agregat, persepsi masyarakat terhadap kualitas hidupnya yang direpresentasikan dengan indeks persepsi menunjukkan bahwa Pangandaran memiliki tingkat kualitas hidup yang lebih baik dibandingkan dengan Palabuhanratu. Temuan ini menegaskan bahwa pendapat Inskeep (1991) dan Jurowski (1994) tentang nilai penting masyarakat dalam perkembangan pariwisata. Kinerja perkembangan destinasi yang baik akan ditandai dengan tingkat kualitas hidup masyarakat yang baik pula. Nilai agregat indeks persepsi kualitas hidup disajikan pada Tabel 3.

Dalam hal aspek material, Pangandaran memiliki nilai indeks persepsi yang lebih baik dibandingkan dengan Palabuhanratu. Dari

Tabel 3

Persepsi Tingkat Kualitas Hidup Masyarakat Lokal Pangandaran dan Palabuhanratu

\begin{tabular}{|l|l|l|l|l|l|}
\hline \multirow{2}{*}{ No } & \multirow{2}{*}{ Aspek } & Rata-rata Tertimbang & Indeks Persepsi \\
\cline { 3 - 6 } & & Pangandaran & Palabuhanratu & Pangandaran & Palabuhanratu \\
\hline I & Material & 71,77 & 70,46 & 21,53 & 21,14 \\
\hline II & Sosial & 68,73 & 69,56 & 17,18 & 17,39 \\
\hline III & Pribadi & 72,39 & 72,09 & 18,10 & 18,02 \\
\hline IV & Spiritual & 79,06 & 77,88 & 15,81 & 15,58 \\
\hline Indeks persepsi rata-rata kualitas hidup & 72,63 & 72,12 \\
\hline
\end{tabular}


komponen-komponen pembentuk aspek material, diketahui bahwa seluruh komponen aspek material di Pangandaran menunjukkan nilai yang lebih tinggi dibandingkan dengan Palabuhanratu. Dua hal yang diduga menyebabkan hal ini terjadi yaitu karakter sosial masyarakat dan etos kerja masyarakat. Karakter sosial masyarakat yang berasal dari nelayan membentuk karakter yang lebih terbuka. Faktor ketidakpastian yang lebih tinggi dibandingkan dengan usaha pertanian menyebabkan masyarakat nelayan harus bekerja yang lebih keras untuk mendapatkan hasil yang memadai. Pola inilah yang kemudian menyebabkan etos kerja masyarakat Pangandaran lebih baik daripada Palabuhanratu.

Interaksi dengan wisatawan juga terjadi dalam bentuk pertukaran barang, jasa, dan pengalaman. Pertukaran dengan wisatawan lebih bersifat ekonomik-kalkulatif, sedangkan pertukaran dengan warga masyarakat lokal lebih berwatak subjektif emosional dan sosial. Temuan ini sesuai dengan penelitian Santosa dan Priyono (2012) yang menyatakan bahwa,

warga desa pada umumnya mementingkan hubungan sosial jika berhubungan dengan sesama warga masyarakat lokal. Bukan berarti tidak rasional, namun interkasi yang terjadi lebih menggunakan logika sosial dari pada logika ekonomi. Dalam hubungan sosial berpola intrinsik, warga lebih mengorbankan kepentingan ekonomi dalam batas tertentu dibandingkan dengan kepentingan sosial kemasyarakatan.

Dalam hal aspek material ini, pekerjaan dianggap merupakan sarana untuk memperoleh pendapatan yang cukup untuk memenuhi kebutuhan pribadi dan keluarga. Tampaknya temuan di atas sejalan dengan yang dikemukakan oleh Liu dan Var (1986), yang menyatakan bahwa perkembangan pariwisata berpengaruh terhadap keterserapan tenaga kerja dan peningkatan pendapatan masyarakat, namun pada saat yang sama akan menyebabkan meningkatnya harga yang berakibat pada peningkatan biaya hidup. Perkembangan pariwasata memang menyebabkan adanya keterserapan tenaga kerja dan peningkatan pendapatan masyarakat Pangandaran, namun pada saat yang sama juga menyebabkan meningkatnya harga-harga kebutuhan di pasar.

Dalam hal aspek sosial, Pangandaran memiliki indeks persepsi yang lebih rendah dibandingkan dengan Palabuharatu. Hal ini diduga menyangkut heterogenitas sosial dan pola relasi sosial. Seperti diketahui
Pangandaran dikembangkan secara multietnis yaitu Jawa dan Sunda sehingga faktor heterogenitas menjadi karakter dasar dari masyarakat Pangandaran. Heterogenitas ini kemudian memudahkan masyarakatnya untuk berrelasi dengan pendatang, namun pada sisi lain cenderung menyebabkan lemahnya ikatan sosial di antara mereka. $\mathrm{Hal}$ ini tercermin dari penyikapan terhadap prostitusi misalnya, masyarakat Pangandaran cenderung lebih kompromistis dibandingkan dengan masyarakat Pelabuhanratu.

Heterogenitas diartikan sebagai keanekaragaman karakter masyarakat menurut suku bangsa. Perbedaan suku bangsa dan tingkat kebiasaan bergaul dengan berbagai suku bangsa menyebabkan penyikapan terhadap wisatawan akan berbeda pula. Heterogenitas dianggap sebagai salah satu modal sosial yang penting bagi berkembangnya suatu destinasi pariwisata. Menurut Nasution et al. (2014) modal sosial dapat didefinisikan sebagai serangkaian nilai dan norma informal yang dimiliki bersama diantara para anggota suatu kelompok masyarakat yang memungkinkan terjadinya kerja sama diantara mereka. Tiga unsur utama dalam modal sosial adalah trust (kepercayaan), reciprocal (timbal balik), dan interaksi sosial. Modal sosial yang baik akan meningkatkan ketiga unsur tersebut yang berakibat pada hubungan yang lebih baik dengan wisatawan.

Nilai indeks persepsi aspek pribadi di Pangandaran lebih tinggi daripada nilai Palabuhanratu. Secara umum aspek pribadi menyangkut pada alokasi hasil usaha untuk pengelolaan kepentingan pribadi. Nilai indeks persepsi yang lebih baik pada masyarakat Pangandaran menunjukkan bahwa masyarakat Pangandaran lebih sadar tentang berbagai makna penting penyikapan terhadap aspek personal. Hal ini secara jelas ditunjukkan oleh perbedaan nilai kepuasan untuk komponen pendidikan. Meskipun secara umum jumlah layanan pendidikan formal di Palabuhanratu lebih banyak dibandingkan dengan Pangandaran namun tingkat kepuasanya lebih rendah. Demikian halnya dengan aspek kesehatan. Meskipun Pangandaran belum memiliki rumah sakit umum, tingkat kepuasan masyarakat terhadap aspek kesehatannya yang lebih tinggi dibandingkan dengan Palabuhanratu. Fakta-fakta tersebut memberi gambaran bahwa masyarakat Pangandaran lebih kreatif untuk menyelesaikan masalah dibandingkan dengan Palabuhanratu. 
Dalam aspek spiritual, Pangandaran memiliki indeks persepsi yang lebih baik dibandingkan dengan Palabuhanratu. Tingkat spiritualitas yang lebih tinggi menyangkut pada penyikapan terhadap perubahan yang terjadi dan diluar kehendak manusia. Peristiwa bencana tsunami pada tahun 2006 tampaknya memberi pelajaran berharga bagi masyarakat Pangandaran untuk lebih menghargai kesempatan yang diperoleh dari Tuhan. Meskipun dalam hal suasana ibadah masyarakat Palabuhanratu lebih baik dibandingkan dengan Pangandaran, namun tidak dalam hal rasa syukur dan penyikapan terhadap keadilan Tuhan. Hal ini mengindikasikan bahwa nilai spiritual yang dipahami masyarakat Palabuhanratu lebih merupakan ibadah ritual seharihari, sementara masyarakat Pangandaran memahami nilai spiritual sebagai penghargaan terhadap anugerah yang diberikan Tuhan.

\section{Pembahasan}

Banyak faktor yang menyebabkan terpengaruhnya persepsi masyarakat tentang kualitas hidupnya, salah satunya adalah perkembangan pariwisata. Perkembangan destinasi pariwisata yang ditandai dengan pertumbuhan jumlah wisatawan dipandang sebagai sesuatu yang positif bagi masyarakat. Alasan pandangan positif tersebut adalah karena perkembangan destinasi berada pada fase meningkat (pertumbuhan dan konsolidasi). Pada kedua fase ini, jumlah wisatawan yang terus tumbuh dipandang masyarakat sebagai agen untuk mendatangkan keuntungan. Orientasi ekonomi yang tinggi menyandarkan pada kedatangan wisatawan. Disamping itu pada kedua fase ini wisatawan telah memiliki pengetahuan yang baik tentang destinasi yang dituju, sehingga telah menjadi kebiasaan kunjungan (Usher dan Kerstetter, 2014).

Penjelasan lain mengapa masyarakat lokal memandang positif perkembangan destinasi pariwisata adalah interaksi yang terjadi antara masyarakat lokal dan wisatawan tidak menyebabkan terganggunya sumber daya alam atau merubah tatanan sosial masyarakat. Interaksi antara masyarakat lokal dan wisatawan merupakan interaksi yang positif dalam arti kedatangan wisatawan menyebabkan terbukanya kesempatan usaha dan kesempatan kerja.

Perasaan positif juga disebabkan oleh kenyataan bahwa masyarakat lokal memperlihatkan kepedulian yang tinggi terhadap pariwisata dan dampaknya terhadap kualitas hidup. Sebagai contoh, penanganan minuman keras dan obat terlarang. Nilai persepsi yang rendah mengindikasikan bahwa tatanan kemasyarakatan masih dipegang teguh meskipun diakui bahwa hal tersebut merupakan dampak pengembangan pariwisata. Namun demikian tingkat toleransi yang tinggi menyebabkan peredaran minuman keras hanya terjadi untuk wisatawan asing di tempat-tempat tertentu.

Masyarakat lokal menyadari bahwa lingkungan merupakan hal yang sangat penting bagi keberlanjutan perikanan dan pariwisata, sebab keduanya merupakan representasi dari pekerjaan utama masyarakat. Meskipun mereka belum menghubungkan degradasi lingkungan dikaitkan dengan pariwisata namun mereka sadar bahwa membuang sampah sembarangan menyebabkan kekumuhan (Usher dan Kerstetter, 2014). Kesadaran ini setidak-tidaknya mengindikasikan bahwa kondisi lingkungan yang baik menyebabkan wisatawan akan kembali datang pada waktu yang akan datang.

Demikian halnya dengan pembangunan destinasi pariwisata, dirancang untuk meningkatkan kualitas hidup masyarakatnya. Hal ini setidak-tidaknya diungkapkan oleh Anderect et al., (2012) bahwa,

perilaku masyarakat dipengaruhi oleh
bagaimana pariwisata dikembangkan. Jika
pengembangan dilakukan dengan baik
maka masyarakat lokal akan memperoleh
manfaat positif. Dengan demikian, se-
makin berkembang destinasi pariwisata,
maka semakin tinggi pula tingkat kualitas
hidupnya. Jika diasumsikan bahwa fase kon-
solidasi merupakan lanjutan dari fase per-
tumbuhan maka seharusnya tingkat kuali-
tas hidup masyarakat Palabuhanratu lebih
tinggi daripada masyarakat Pangandaran.

Secara agregat, nilai indeks persepsi kualitas hidup Pangandaran lebih baik dibandingkan dengan nilai indeks persepsi kualitas hidup Palabuhanratu. Indeks persepsi yang lebih baik tersebut didukung oleh aspek material, aspek pribadi dan aspek spiritual. Jika dibandingkan dengan kinerja perkembangan pariwisata, Pangandaran juga memiliki nilai yang lebih baik. Data perkembangan pariwisata menunjukkan bahwa hampir semua aspek perkembangan destinasi pariwisata, skor perkembangan Pangandaran lebih tinggi dibandingkan dengan skor perkembangan Palabuhanratu. Hal ini menunjukkan bahwa destinasi pada fase pertumbuhan justru memiliki nilai yang lebih baik dibandingkan fase konsolidasi. Dengan demikian, meskipun fase konsolidasi 
merupakan lanjutan dari fase pertumbuhan, namun tingkat kualitas hidup destinasi pariwisata ditentukan oleh dampak pengganda dari pertumbuhan jumlah wisatawan.

Dampak pengganda berkaitan dengan peningkatan kualitas hidup dimulai dari peningkatan pendapatan masyarakat. Peningkatan pendapatan menyebabkan alokasi dana untuk kebutuhan sosial, pribadi, dan spiritual meningkat juga. Temuan ini memperkuat pendapat Inskeep (1991) bahwa pengembangan kawasan pariwisata akan berhasil jika mampu meningkatkan keterpaduan dan kesatuan pembangunan masyarakat. Masyarakat merupakan salah satu komponen penting dan keterlibatannya sangat menentukan keberhasilan pembangunan.

Kontribusi perkembangan destinasi terhadap tingkat kualitas hidup masyarakat lokal dijelaskan dalam pola sebagaimana pada gambar 3.

Perkembangan destinasi pariwisata yang ditandai dengan perkembangan wisatawan dan akomodasi, direspon oleh masyarakat lokal dan stakeholder lainnya dalam bentuk pembangunan destinasi pariwisata. Pembangunan pada gilirannya akan melibatkan masyarakat baik dalam perencanaan, implementasi maupun pengwasannya. Hasil dari keterlibatan masyarakat tersebut adalah kesempatan untuk mendapatkan pekerjaan dan penghasilan yang baik. Alokasi pendapatan yang diperoleh digunakan dengan skala prioritas seperti disebut sebelumnya.

Penelitian Kim (2002) menyatakan bahwa tidak terdapat efek moderasi fase perkembangan destinasi pariwisata, terhadap hubungan antara dengan kualitas hidup dan persepsi masyarakat terhadap pariwisata. Dengan demikian, fase perkembangan pariwisata tidak memberikan pengaruh pada kualitas hubungan keduanya. Tampaknya temuan penelitian ini sesuai dengan kesimpulan Kim (2002) tersebut. Masyarakat kedua wilayah memandang kedatangan wisatawan dengan cara yang sama, namun alokasi penggunaan pendapatan menjadi pembeda antara Pangandaran dan Palabuhanratu.

\section{Simpulan dan Saran}

Kesimpulan yang diperoleh dari pembahasan ini adalah Pangandaran memiliki tingkat perkembangan destinasi pariwisata yang lebih baik dibandingkan dengan Palabuhanratu. Pangandaran berada pada fase pertumbuhan dan Palabuhanratu berada pada fase konsolidasi jika di plot dalam model Butler (1980).

Beberapa hal khusus yang ditemukan

\section{Gambar 3 \\ Bagan Alur Hubungan antara Perkembangan Destinasi, Keterlibatan Masyarakat dan Alokasi Pendapatan}

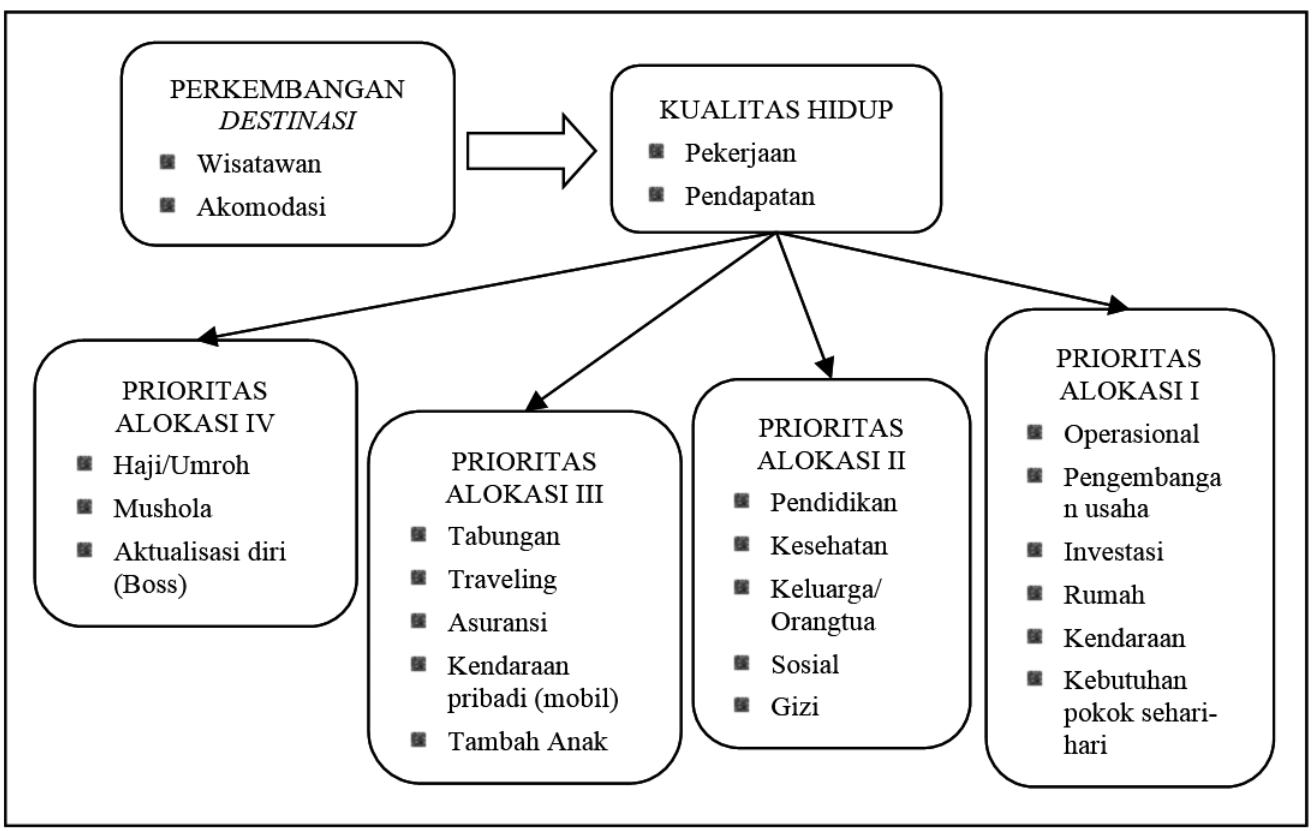


adalah sebagai berikut:

Pada kedua fase perkembangan terjadi jumlah kunjungan wisatawan yang tinggi menunjukkan bahwa konsep pengembangan destinasi pariwisata yang dianut adalah konsep pariwisata masal. Pola kunjungan wisatawan dicirikan oleh melonjaknya jumlah kunjungan pada masa liburan sekolah dan hari raya, dan kunjungan rendah pada harihari biasa.

Perkembangan jumlah wisatawan merangsang masyarakat lokal berusaha secara informal. Kedekatan geografis daerah asal wisatawan dan destinasi pariwisata memunculkan karakter lokal wisatawan. Karakter lokal menyebabkan tidak berkembangnya usaha-usaha akomodasi.

Persepsi masyarakat lokal terhadap tingkat kualitas hidupnya menunjukkan tingkat yang tinggi pada kedua lokasi. Diantara keempat aspek kualitas hidup, aspek material berada pada posisi tertinggi disusul oleh aspek spiritual, aspek sosial dan aspek pribadi. Beberapa hal khusus yang ditemukan adalah sebagai berikut: (1) Indeks persepsi kualitas hidup yang diperoleh menunjukkan bahwa Pangandaran memiliki nilai yang lebih baik dibandingkan dengan Palabuhanratu; (2) dalam hal aspek material, Pangandaran memiliki nilai indeks persepsi yang lebih baik dibandingkan dengan Palabuhanratu. Dua hal yang menyebabkan hal ini terjadi yaitu karakter sosial masyarakat dan etos kerja masyarakat; (3) dalam hal aspek sosial, Pangandaran memiliki indeks persepsi yang lebih rendah dibandingkan dengan Palabuharatu. Hal ini menyangkut pada karakter heterogen masyarakat. Heterogentitas ini kemudian memudahkan masyarakatnya untuk berrelasi dengan pendatang. Namun, pada sisi lain cenderung menyebabkan lemahnya ikatan sosial di antara mereka; (4) dalam hal aspek pribadi, Pangandaran memiliki indeks persepsi yang lebih tinggi daripada nilai Palabuhanratu. Meskipun secara umum jumlah layanan aspek pribadi lebih rendah, namun masyarakat Pangandaran memiliki kreativitas untuk menyelesaikan masalah yang lebih baik dibandingkan dengan Palabuhanratu; (5) Dalam hal aspek spiritual, Pangandaran memiliki indeks persepsi yang lebih baik dibandingkan dengan Palabuhanratu. Nilai spiritual dipahami oleh masyarakat Palabuhanratu merupakan ibadah ritual seharihari, sementara masyarakat Pangandaran memahaminya sebagai penghargaan terhadap anugerah yang diberikan Tuhan.
Terdapat hubungan positif antara perkembangan destinasi pariwisata dengan kualitas hidup masyarakat lokal. Hubungan terjadi dipicu oleh pertumbuhan jumlah wisatawan yang memberikan dampak berupa pekerjaan dan usaha. Alokasi hasil hasil usaha tersebut digunakan untuk menjamin kualitas hidup yang lebih baik terdiri dari empat aspek kualitas hidup berupa material, sosial, pribadi, dan spiritual.

Rekomendasi yang disampaikan adalah Perkembangan destinasi pariwisata harus dimaknai sebagai perkembangan jumlah wisatawan yang dapat memberikan dampak pada peningkatan atribut destinasi lainnya, dan peningkatan kualitas hidup masyarakat secara keseluruhan. Perlu dilakukan upaya untuk mengangkat aspek pribadi dalam kualitas hidup masyarakat lokal dengan mengungkapkan keunggulan-keunggulan modal sosial yang dimiliki yaitu aspek sosial dan spiritual yang tinggi.

\section{Daftar Pustaka}

Andereck, K., dan Vogt, C. (2000). The relationship between residents' attitudes toward tourism and tourism development options. Journal of Travel Research Vol. 39 No.1, 27-36.

Aref, F. (2011). The Effects of Tourism on Quality of Life: A Case Study of Shiraz, Iran. Life Science Journal, Volume 8, Issue 2 , 2630.

Benckendorff, P., Edwards, D., Jurowski, C., Liburd, J. J., Miller, G., dan Moscardo, G. (2009). Exploring the Future of Tourism and Quality of Life. Tourism and Hospitality Research Volume 9 No.2, 171-183.

Buhalis, D. (2000). Marketing the Competitive Destination of the Future. Tourism Management, 1-15.

Butler, R. (1980). The Concept of a Tourist Area of Life Cycle of Evolution: Implications for Management of Resource. Canadian Geographer Volume 19 No.1 , 5-12.

Butler, R. (2011). Tourism Area Life Cycle. Oxford: Goodfellow Publisher.

Dietrich, A., dan García, E. (2008). Locals Perceptions of Tourism as Indicators of Destination Decline. Tourism Management, $30,1-10$.

Dyer, P., Gursoy, D., Sharma, B., \& Carter, J. (2006). Dyer, P., D. Gursoy, B. Sharma and J. Carter (2006). Structural Modeling of Residents ' Perceptions of Tourism and . Tourism Management 28 , 409-422.

E.Eraqi, M. (2007). Local Community Attituted toward Tourism Development in Egypt. Tourism Analysis, Volume 12 , 191-200.

Fandeli, C., dan Nurdin, M. (2005). Pengembangan 
Ekowisata Berbasis Konservasi di Taman Nasional. Yogyakarta: UGM Press.

Fauzi, A., \& Oktavianus, A. (2014). Pengukuran Pembangunan Berkelanjutan di Indonesia. Mimbar Vol. 30, No.1 , 42-52.

Goncalves, V. F., dan Aguas, P. M. (1997). The concept of life cycle: an application to the tourist product. Journal of Travel Research Volume 36 No. 2 , 12-22.

Gunn, C. A., \& Var, T. (1994). Tourism Planning: Basics, Concepts, Cases. New York: McGraw Hill.

Inskeep, E. (1991). Tourism planning: an integrated and sustainable development approach. New York: Van Nostrand Reinhold.

Johnson, J., Snepenger, D. J., dan Akis, S. (1994). Residents' perceptions of tourism development. Annals of Tourism Research, $21,629-642$.

Jurowski, C. (1994). The Interplay of Elements Affecting Host Community Resident attitudes toward tourism: A path analytic approach. Blacksburg, Virginia.: Virginia Polytechnic Institute and State University.

Jurowski, C., dan Brown, D. O. (2001). A Comparison of the Views of Involved Versus Noninvolved Citizens on Quality of Life and Tourism Development Issues. Hospitality dan Tourism Research, 355370.

Kim, K. (2002). The effects of tourism impacts upon Quality of Life of residents in the community. Blacksburg, Virginia: Virginia Polytechnic Institute and State University.

Liu, J. C., dan Var, T. (1986). Resident attitudes toward tourism impacts in Hawaii. Annals Tourism Research Volume 13 Issue 2, 193-214.
Morris, M., \& Alpin, M. (1982). Measuring the Condition of India's Poor. New Delhi: Promilla Co. Publisher.

Nasution, A., Rustiadi, E., Juanda, B., \& Hadi, S. (2014). Dampak Modal Sosial terhadap Kesejahteraan Rumahtangga Perdesaan di Indonesia. Mimbar Vol. 30, No. 2 , 137-148.

Santosa, I., \& Priyono, R. E. (2012). Diseminasi Model Pemberdayaan Masyarakat Desa melalui Agrowisata. Mimbar Vol. 28, No. $2,181-190$.

Saraniemi, S., dan Kylänen, M. (2011). Problematizing the Concept of Tourism Destination: An Analysis of Different Theoretical Approaches. Journal of Travel Research vol. 50 no. 2 , 133-143.

Seetanah, B., Juwaheer, T., Lamport, M., Rojid, S., Sannase, R., dan Subadar, A. (2011). Does Infrastructure Matter In Tourism Development? University of Mauritius Journal Vol. 17 , 89-107.

Sheldon, P. J., dan Abenoja, T. (2001). Resident attitudes in a mature destination: the case of Waikiki. Tourism Management Vol.2 Issue $5,435-443$.

Susniene, D., dan Jurkauskas, A. (2009). The Concepts of Quality of Life and Happiness - Correlation and Differences. Inzinerine Ekonomika-Engineering Economics Volume 1 , 58-66.

UNWTO. (2010). UNWTO Tourism Highlight 2010 Edition. New York: UNWTO Publications Department.

Usher, L. E., \& Kerstetter, D. (2014). Residens' Perception of Quality of Life in a Surf Tourism Destination: A case Study of Las Salinas, Nicaragua. Progress in Development Studies Vol. 14, No. 4 , 321-333. 